\title{
The Effect of Half Plunging and No Plunging as Alternative Winemaking Techniques on Phenolic Extraction and Pigment Composition of Wine
}

\author{
R. Chittenden ${ }^{1 *}$, M. Annand ${ }^{1}$, P. King ${ }^{1}$, G. Russell ${ }^{2}$ \\ (1) School of Applied Science, Eastern Institute of Technology, Private Bag 1201, Hawke's Bay Mail Centre, Napier, New \\ Zealand \\ (2) Esk Valley Estate, PO Box 111, Bay View Napier, NZ
}

Submitted for publication: August 2014

Accepted for publication: September 2014

Key words: Anthocyanins, pigmented tannins, tannins, phenolics, alternative, Merlot

\begin{abstract}
The extraction of phenolics (anthocyanins, total phenolics and tannins) and pigmented tannin evolution in Merlot red wines made using three different winemaking techniques were evaluated over one year. Traditional maceration (TM) (two plunges per day), half plunging (half) and no plunging (NP) methods were compared using triplicate $12 \mathrm{~kg}$ vinification. No pre-fermentation maceration occurred and a 15-day fermentation and post-fermentation period was used. The wines were analysed daily during the 15-day maceration period and regularly after pressing during the next 11 months. Phenolic, tannin and colour measurements were analysed using UV/Vis spectral readings processed using the AWRI WineCloud ${ }^{\mathrm{TM}}$. At the end of the 15-day maceration, total phenolics, total pigment and free anthocyanins were significantly lower in concentration in the TM treatment compared with NP. The tannin concentration also was significantly lower from days 10 to 12 . Pigmented tannin was consistently at higher concentrations in the TM treatment, although not significantly so, during maceration. The significant differences were maintained as the wine developed over the next 11 months; however, the NP trial wine displayed increased pigmented tannin development compared with the TM, being significantly higher in pigmented tannin from about day 90. Higher colour and phenolic extraction in the NP trial led to higher stable colour development in the resulting wines, with the winemaking having an important effect in modifying the pigment profile of the wines. General wine quality parameters did not differ significantly between the three treatments.
\end{abstract}

\section{INTRODUCTION}

Phenolic compounds extracted from grapes are important for their contribution to the quality of red wine colour, mouthfeel and stability. Traditionally, phenolics are extracted during fermentation and maceration, processes usually involving mechanical mixing of the must, including the grape skins and seeds. It is believed that the mixing process during maceration enhances the diffusion and movement of phenolic compounds from the skin and seeds into the juice/ wine (Sacchi et al., 2005; Ribereau-Gayon et al., 2006). In a review of the effects of winemaking techniques on phenolic extraction in red wines, Sacchi et al. (2005) concluded that fermentation temperature, thermo-vinification, must freezing, saignee, pectolytic enzyme treatments and extended maceration increased phenolic concentration, whereas $\mathrm{SO}_{2}$ levels and cold soak treatments had little or no lasting effects or led to a decrease in phenolic levels.

Flavanoid phenolic compounds, including anthocyanins, flavan-3-ols and flavonols, are found in the skins and seeds of grape berries. Anthocyanins are fundamental components of young red wine colour and are extracted from the grape skins, along with flavonols such as quercetin and myricetin, which contribute to wine bitterness. Monomeric flavan-3-ols, such as catechins, are extracted from seeds and polymerise to form proanthocyanidin structures, which contribute to wine astringency (Gawel, 1998; Cheynier et al., 2006; Fulcrand et al., 2006). Extended maceration post-fermentation is often encouraged to enhance the extraction of skin and seed tannins. These tannins, in the presence of high levels of anthocyanins and with controlled introduction of oxygen, lead to the development of ethanal-linked polymerisation structures that incorporate anthocyanins as end units (EsSafi et al., 1999; Cheynier et al., 2006). These structures are important for stabilising colour in the resulting red wines (Vrhovsek et al., 2002; Sacchi et al., 2005). Traditionally, pump overs, punching down, roto fermenters and air pulsing have been used to encourage the mixing during and after the fermentation maceration time. Punching down and roto treatments yielded the highest total polyphenol concentrations and the pump-over treatment the lowest concentrations in a study by Marais (2003). Temperature, maceration length, pectolytic enzyme addition and alcohol 
concentration are other factors that affect the final phenolic composition of the wine (Gao et al., 1997; Sacchi et al., 2005; De Beer et al., 2006).

Winemakers deeply value coloured and fuller bodied red wines (Lattey et al., 2010). The factors and conditions detailed above are used by winemakers in an attempt to produce wines displaying these desired characteristics. However, grape solid and wine contact time seems to be the main factor involved (Kovac et al., 1992; Gil et al., 2012). Gil et al. (2012) and Kovac et al. (1992) found that proanthocyanidin extraction from seeds increased throughout maceration. Cerpa-Calderon and Kennedy (2008) found that skin proanthocyanidins from treatments with greater degrees of berry crushing reached higher proportions of total extracted proanthocyanidins earlier than treatments with less berry crushing. They also found that skin anthocyanidins were extracted earlier than seed proanthocyanidins. Casassa et al. (2013) discovered that the tannin content of wine produced with extended maceration ( 30 days' skin contact) was derived mainly from seed tannins, whereas tannins from traditional ten-day skin contact wines had balanced proportions of seed and skin tannins. Anthocyanin concentration was lower in wines with extended maceration because the synthesis of longer polymer pigments during post-fermentation maceration removed monomer anthocyanins faster than in the control. In a qualitative analysis of tannins in grape and seed/skin pomace samples post-maceration, Casassa et al. (2013) suggested that a rebinding or incorporation of previously extracted seed tannins into skin tannins occurred during maceration. The opposite process, of skin tannins incorporated into seed tannins, was not observed.

In a comprehensive study of the delayed extraction of anthocyanins and separation of must, Bosso et al. (2009) reported that, at racking, the wines produced with the delayed extraction techniques were higher in colour, total and monomeric anthocyanins and total phenolics than the wines produced by traditional red wine maceration techniques. These differences remained after seven months of ageing. In another study on delayed extraction of anthocyanins, by Gonzales-Nevez et al. (2010), the pigment in the control wines was higher at all times, but after one year the total pigment content of the wines showed no significant difference between traditional maceration and delayed extraction.

Winemakers may wish to employ red wine maceration techniques that result in higher concentrations of anthocyanins. A panel of experienced wine tasters (winemakers) considered higher quality red wines to be darker in overall colour, bigger in mouthfeel, hotter and astringent (Lattey et al., 2010). Kilmister et al. (2014) found that fruit anthocyanin concentration correlated with wine tannin concentration, wine colour and polymeric pigment. They proposed that anthocyanin concentration may be a key component for increasing tannin solubility and extraction into wine, and for the formation of polymeric pigments. This is in agreement with previous suggestions by Singleton and Trousdale (1992). In a sensory and chemical study of phenolic polymers in red wines, Weber et al. (2013) reported that astringency in red wines decreased with increasing incorporation of anthocyanins into polymeric structures, and that high molecular weight pigmented polymers evoked the lowest astringency ratings.

In view of this evidence for a key role for phenolics in wine composition and quality, this study aimed to evaluate further the effect of different winemaking techniques on the phenolic and pigment composition of Merlot red wines. The wines were made using three different maceration regimes: traditional maceration, half usual plunging and no plunging at all. Wines were then analysed over an extended period to establish compositional benefits or outcomes.

\section{MATERIALS AND METHODS}

Three $12 \mathrm{~kg}$ replicates were used for each winemaking procedure. Hawke's Bay Merlot grapes from the 2013 vintage at Esk Valley Estate were destemmed and crushed with an Enoveneta N15T391 (Italy) machine and, after homogenising of the must, divided into nine $15 \mathrm{~L}$ capacity plastic fermentation containers with carbon dioxide gas cover (three replicates of three treatments). Must composition analysis was recorded as $23.5^{\circ}$ Brix, $4.8 \mathrm{~g} / \mathrm{L}$ tartaric acid equivalent titratable acidity, and $\mathrm{pH} 3.43$, using classical methods (Iland et al., 1993). No pre-fermentation $\mathrm{SO}_{2}$ additions were made. Traditional maceration (TM), half plunging (half) and no plunging (NP) were the winemaking techniques compared, with the TM used as the control treatment. Inoculation with Lalvin ICV D254 yeast was carried out at $250 \mathrm{mg} / \mathrm{kg}$, and Lallemand Fermaid A plus diammonium phosphate was added once fermentation started, in three steps of $0.1 \mathrm{~g} / \mathrm{kg}$ each after a $2^{\circ}$ Brix change, and then again at $16^{\circ}$ Brix and $12^{\circ}$ Brix. Malolactic bacteria were inoculated at the manufacturer's rate using CHR Hansen CH16 with nutrients via Lallemand Optimalo Plus at a rate of $0.1 \mathrm{~g} / \mathrm{kg}$ when $3^{\circ}$ Brix was reached.

The control wines (TM) were made using classical fermentation and maceration on the skins for 15 days, with plunging undertaken as 12 plunges each time, twice per day for each of the 15 days. The temperature of the fermentations was maintained at 26 to $33^{\circ} \mathrm{C}$ in a temperature-controlled room set at $26^{\circ} \mathrm{C}$ to maintain realistic commercial fermentation temperatures for the 15 days of maceration. The half plunged wines (Half) were made identically to the TM wines, except the 12 plunges each twice a day did not commence until day 7 and continued for the rest of the 15 days of maceration. The NP wines were also treated identically to the TM wines; however, no plunging took place at all over the entire 15-day maceration period, other than when the addition of nutrients and malolactic bacteria took place. At these points a small plastic tube was carefully inserted through the skin cap to allow the introduction of the additive, followed by careful mixing using a small rod through the tube to allow stirring of the fermenting liquid under the cap. Sampling took place after such stirring, ensuring that a homogenous solution/ wine composition was available for extraction.

At the time of pressing, free-run wine was drained through the stainless steel screen of an Enotecnica Pillan (Vincenza, Italy) $20 \mathrm{~kg}$ capacity water bladder basket press, followed by pressing to 2 bar pressure, and the press wine was combined with the free run in all trials. Wines were stored in plastic containers until malolactic fermentation was completed, at which time $50 \mathrm{mg} / \mathrm{L} \mathrm{SO}_{2}$ was added following racking. All wines were stored at $13^{\circ} \mathrm{C}$ in closed plastic 5L 
containers, with free $\mathrm{SO}_{2}$ maintained at $25 \mathrm{mg} / \mathrm{L}$.

Each wine trial and replicate were analysed, using classical methods (Iland et al., 1993) 12 months after vinification, and mean values for each treatment were calculated for alcohol, titratable acidity, $\mathrm{pH}$, volatile acidity, residual sugar, and free and total $\mathrm{SO}_{2}$.

Wine total phenolics, total tannin, total pigment (total red colour), free anthocyanins and pigmented tannins were evaluated using the Australian Wine Research Institute WineCloud $^{\mathrm{TM}}$ (AWRI, 2012) using a Beckman Coulter DU 730 Life Science UV/Vis Spectrophotometer. Analyses were based on 250, 270, 280, 290, 315, 320, 520 and $520\left(\mathrm{SO}_{2}+\right.$ buffered) nm UV-Vis spectral absorbance readings that used the calibrations and the database maintained by AWRI. This data base is made up of more than 8000 mainly Australian and New Zealand finished and fermenting wine sample spectral characteristics. The tannin assay is based on the methyl cellulose precipitable (MCP) tannin assay (Sarneckis et al., 2006) and is incorporated into the WineCloud ${ }^{\mathrm{TM}}$, along with measurements of wine pigment (total anthocyanins), free $\left(\mathrm{SO}_{2}\right.$ bleachable) anthocyanins, pigmented (nonbleachable) tannins and total phenolics. Dambergs et al. (2012) developed a predictive algorithm based on the MCP method using UV-Vis spectral measurements for calculating tannin concentration. Analytical data developed using this method can be related directly to measurements made using the Adams-Harbertson $(\mathrm{A}-\mathrm{H})$ protein precipitation tannin analysis method (Hagerman \& Butler, 1978). The MCP and A-H methods have been compared (Harbertson et al., 2003; Mercurio \& Smith, 2008; Harbertson \& Downey, 2009; Chittenden \& Smith, 2011) and the results show that tannin concentrations generated by the MCP method (as utilised by the WineCloud ${ }^{\mathrm{TM}}$ ) are highly correlated with those generated by the A-H assay. The WineCloud ${ }^{\mathrm{TM}}$ incorporates the AWRI's standard method (Iland et al., 2004) for the measurement of grape anthocyanins and phenolics. Relative colour and pigment data are distinguished via the WineCloud ${ }^{\mathrm{TM}}$ on the basis of these standard methods using the absorbances at the described wavelengths to generate the relative data presented. Algorithms for this purpose are based on results from analyses according to the modified Somers and Evans assay (1977), as reported by Mercurio et al. (2007).

The statistical analysis of all the data was expressed as the arithmetic average of three replicates. ANOVA was conducted using Minitab 15.1.0.0. ANOVA attempts to describe the relationship between several means, providing a measure of difference between treatments within the same characteristics. Tukey's procedure was used to indicate significance at the $p<0.05$ level.

\section{RESULTS AND DISCUSSION}

Table 1 shows the wine composition of the three treatments 11 months after winemaking. Given that each trial used identical homogenised grape must, variations in alcohol, titratable acidity, $\mathrm{pH}$, colour and polyphenol composition of the wines for the three different treatments would have to be due to the different treatments applied.

An expected increase in wine volatile acidity (VA) due to bacterial action in the undisturbed cap of the Half and NP treatments compared to the TM treatment was not observed, indicating that initial VA production due to cap drying and exposure to air was not an issue. Alcohol and total $\mathrm{SO}_{2}$ levels were not significantly different for the three treatments. Overall total $\mathrm{SO}_{2}$ concentrations were high in all treatments due to the inherent difficulties of the large surface-area-tovolume ratios in small-scale wine making. All fermentations went 'dry', with TM showing lower residual sugar than the Half and NP treatments. Both delayed extraction methods produced wines with slightly higher TA and lower $\mathrm{pH}$ than the TM trial. Table 1 shows that the TA and $\mathrm{pH}$ of the TM treatment were significantly lower compared with NP. This is in agreement with the findings of a study by Bosso et al. (2011), in which a trial using mechanical effects on a floating cap by pump overs was compared with a submerged cap. Pump overs led to increased extraction of $\mathrm{K}^{+}$, which resulted in more precipitation of potassium bitartrate. The possible increased precipitation of potassium bitartrate in our TM trial resulted in a lower eventual TA compared with the Half and NP treatments. This possible increase in precipitation of potassium bitartrate along with extracted anthocyanins is referred to elsewhere in this discussion.

Tannin concentrations for the treatments are reported in Table 2, and show that tannins increase as ethanol concentration increases over the maceration period, as previously reported by Canals et al. (2005).

The NP treatment consistently showed the highest extraction of tannins during this period, although this was

TABLE 1

General composition of Merlot wines at 12 months.

\begin{tabular}{lllll}
\hline Variety & Winemaking & Titratable acidity & $\mathrm{pH}$ & Volatile acidity \\
\hline \multirow{3}{*}{ Merlot } & TM & $5.52 \mathrm{~b} \pm 0.06$ & $3.53 \mathrm{~b} \pm 0.01$ & $0.310 \mathrm{a} \pm 0.012$ \\
& Half & $5.77 \mathrm{a} \pm 0.03$ & $3.51 \mathrm{a} \pm 0.01$ & $0.354 \mathrm{a} \pm 0.016$ \\
\hline Variety & NP & $5.75 \mathrm{a} \pm 0.10$ & $3.51 \mathrm{a} \pm 0.01$ & $0.354 \mathrm{a} \pm 0.036$ \\
\hline \multirow{3}{*}{ Merlot } & Winemaking & Alcohol & Residual sugars & Total SO \\
& TM & $12.8 \mathrm{a} \pm 0.3$ & $1.0 \mathrm{a} \pm 0.0$ & $151 \mathrm{a} \pm 15$ \\
\hline
\end{tabular}

Mean values $(n=3) \pm$ standard deviations. Values with the same letter in the same columns mean that there are no statistically significant differences according to a Tukey test $(\mathrm{p}<0.05)$. Titratable acidity expressed as $\mathrm{g} / \mathrm{L}$ tartaric equivalent; volatile acidity as $\mathrm{g} / \mathrm{L}$ acetic acid equivalent; alcohol as $\%(\mathrm{v} / \mathrm{v})$; residual sugar in glucose $\mathrm{g} / \mathrm{L}$; total $\mathrm{SO}_{2}$ in $\mathrm{mg} / \mathrm{L}$. TM: traditional maceration. Half: half plunged. NP: not plunged. 
significant on day 10 and day 12 only. The TM treatment followed similar levels to the NP until day 8, from when it declined steadily, whereas the NP tannin concentration merely flattened at this stage. By day 14 no significant tannin extraction differences between the two trials were observed. Table 3 shows that the extraction of total phenolics and levels in the NP treatment were significantly higher than TM on 11 of the 14 sampling days.

Concentrations in total phenolics followed a similar steady increase, as did tannins, over the first 3 days. From day 5 onwards the NP trial showed higher total phenolics than the TM trial. During this period the rate of increase in total phenolics for both treatments steadied and even showed a slight decline by day 14 This compares with the findings of Marais (2003) and Bosso et al. (2011), with similar levelling and declines in total flavonoids and tannins reported during the later stages of maceration. Total pigment levels are shown in Table 4 and demonstrate the classic reported pattern of extraction during maceration, peaking at or about day 6 for both the TM and NP treatments (Ribereau-Gayon et al., 2006; Chittenden, 2008)

However, NP total pigment was significantly higher than that of the TM treatment from day 3 right through to day 14, indicating that the NP regime favoured the extraction of anthocyanins more than the TM trial. Although fermentation temperatures measured as juice/fermenting liquid temperatures were similar for each treatment over the maceration period, the completely undisturbed cap of the NP trial was at higher cap temperatures than the TM trial for greater periods. Cap temperatures were noted as greater than fermenting juice temperature in each trial, and in the NP trial this higher cap temperature was not "cooled" at each plunging episode as it was in the TM trial. This may have resulted in higher anthocyanin extraction. Gao et al. (1997) found that increased fermentation temperatures gave rise to increased monomeric anthocyanin extraction. Very reactive anthocyanins may also be being removed from the TM treatment to a greater extent compared to the NP treatment. This is in agreement with the data in Table 5, which shows the levels of free monomeric anthocyanins during the fermentation maceration period.

Again, the NP trial consistently showed significantly higher levels of free anthocyanins than the TM trial through days 3 to 14 . The oxidation of anthocyanins has previously been proposed to be one of the major reasons for the apparent loss of anthocyanins during red wine maceration (Bosso et al., 2009; 2011). Anthocyanins are very reactive phenolic compounds and, as they are extracted during the early aqueous stage of fermentation, they can become oxidised due to catalytic polyphenol oxidase oxidation and coupled oxidation due to $\mathrm{O}_{2}$ contact with the fermenting must.

Table 6 shows that, during the 14-day maceration period,

TABLE 2

Tannins during maceration.

\begin{tabular}{llllll}
\hline & Day 1 & Day 2 & Day 3 & Day 4 & Day 5 \\
\hline TM & $0.49 \mathrm{a} \pm 0.03$ & $0.72 \mathrm{a} \pm 0.10$ & $1.03 \mathrm{a} \pm 0.06$ & $1.39 \mathrm{a} \pm 0.14$ & $1.64 \mathrm{a} \pm 0.19$ \\
$\mathrm{NP}$ & $0.47 \mathrm{a} \pm 0.01$ & $0.53 \mathrm{a} \pm 0.18$ & $1.15 \mathrm{a} \pm 0.04$ & $1.42 \mathrm{a} \pm 0.04$ & $1.92 \mathrm{a} \pm 0.12$ \\
\hline & Day 6 & Day 7 & Day 8 & Day 9 & Day 10 \\
\hline TM & $2.09 \mathrm{a} \pm 0.18$ & $2.09 \mathrm{a} \pm 0.06$ & $2.04 \mathrm{a} \pm 0.14$ & $1.98 \mathrm{a} \pm 0.28$ & $1.81 \mathrm{~b} \pm 0.10$ \\
$\mathrm{NP}$ & $2.17 \mathrm{a} \pm 0.03$ & $2.20 \mathrm{a} \pm 0.20$ & $2.05 \mathrm{a} \pm 0.11$ & $2.15 \mathrm{a} \pm 0.24$ & $2.28 \mathrm{a} \pm 0.15$ \\
\hline & Day 11 & Day 12 & Day 13 & Day 14 & \\
\hline $\mathrm{TM}$ & $1.78 \mathrm{a} \pm 0.06$ & $1.82 \mathrm{~b} \pm 0.10$ & $1.76 \mathrm{a} \pm 0.11$ & $1.83 \mathrm{a} \pm 0.16$ & \\
$\mathrm{NP}$ & $2.27 \mathrm{a} \pm 0.17$ & $2.19 \mathrm{a} \pm 0.20$ & $2.15 \mathrm{a} \pm 0.17$ & $1.98 \mathrm{a} \pm 0.13$ & \\
\hline
\end{tabular}

Mean values \pm standard deviations. $\mathrm{N}=3$. Tannins in $\mathrm{g} / \mathrm{L}$ epicatechin equivalent (AWRI WineCloud ${ }^{\mathrm{TM}}$ ). Values with the same letter in the same column on the same day mean there are no statistically significant differences according to the Tukey test $(\mathrm{p}<0.05)$. TM: traditional maceration. NP: not plunged.

TABLE 3

Total phenolics during maceration.

\begin{tabular}{llllll}
\hline & Day 1 & Day 2 & Day 3 & Day 4 & Day 5 \\
\hline TM & $37.39 \mathrm{a} \pm 1.10$ & $46.84 \mathrm{a} \pm 3.29$ & $48.16 \mathrm{~b} \pm 2.43$ & $54.40 \mathrm{~b} \pm 4.16$ & $57.75 \mathrm{~b} \pm 7.27$ \\
NP & $37.30 \mathrm{a} \pm 0.49$ & $42.04 \mathrm{a} \pm 4.50$ & $58.64 \mathrm{a} \pm 3.29$ & $63.30 \mathrm{a} \pm 2.22$ & $74.64 \mathrm{a} \pm 2.47$ \\
\hline & Day 6 & Day 7 & Day 8 & Day 9 & Day 10 \\
\hline TM & $67.19 \mathrm{~b} \pm 2.90$ & $63.78 \mathrm{~b} \pm 1.85$ & $61.44 \mathrm{~b} \pm 4.08$ & $65.83 \mathrm{a} \pm 4.00$ & $61.63 \mathrm{~b} \pm 1.76$ \\
NP & $77.11 \mathrm{a} \pm 0.62$ & $74.64 \mathrm{a} \pm 3.48$ & $72.10 \mathrm{a} \pm 1.64$ & $73.67 \mathrm{a} \pm 3.65$ & $76.54 \mathrm{a} \pm 1.75$ \\
\hline & Day 11 & Day 12 & Day 13 & Day 14 & \\
\hline TM & $61.31 \mathrm{~b} \pm 0.42$ & $62.37 \mathrm{~b} \pm 1.82$ & $60.93 \mathrm{~b} \pm 2.47$ & $63.23 \mathrm{~b} \pm 3.08$ & \\
\hline NP & $75.54 \mathrm{a} \pm 3.95$ & $75.12 \mathrm{a} \pm 4.95$ & $74.78 \mathrm{a} \pm 2.33$ & $70.19 \mathrm{a} \pm 2.33$ &
\end{tabular}

Mean values \pm standard deviations. $\mathrm{N}=3$. Total phenolics in AU (AWRI WineCloud ${ }^{\mathrm{TM}}$ ). Values with the same letter in the same column on the same day mean there are no statistically significant differences according to the Tukey test $(\mathrm{p}<0.05)$. TM: traditional maceration. NP: not plunged. 
TABLE 4

Total pigments during maceration.

\begin{tabular}{llllll}
\hline & Day 1 & Day 2 & Day 3 & Day 4 & Day 5 \\
\hline TM & $21.71 \mathrm{a} \pm 0.85$ & $31.40 \mathrm{a} \pm 2.16$ & $30.60 \mathrm{~b} \pm 1.36$ & $32.13 \mathrm{~b} \pm 2.83$ & $32.11 \mathrm{~b} \pm 4.60$ \\
NP & $21.81 \mathrm{a} \pm 0.72$ & $28.25 \mathrm{a} \pm 3.28$ & $37.91 \mathrm{a} \pm 2.77$ & $38.73 \mathrm{a} \pm 1.53$ & $44.25 \mathrm{a} \pm 1.90$ \\
\hline & Day 6 & Day 7 & Day 8 & Day 9 & Day 10 \\
\hline TM & $35.77 \mathrm{~b} \pm 1.46$ & $31.35 \mathrm{~b} \pm 1.11$ & $29.02 \mathrm{~b} \pm 2.21$ & $29.63 \mathrm{~b} \pm 2.00$ & $26.04 \mathrm{~b} \pm 0.95$ \\
NP & $43.74 \mathrm{a} \pm 0.38$ & $39.51 \mathrm{a} \pm 2.71$ & $36.58 \mathrm{a} \pm 0.98$ & $36.53 \mathrm{a} \pm 1.76$ & $37.59 \mathrm{a} \pm 0.98$ \\
\hline & Day 11 & Day 12 & Day 13 & Day 14 & \\
\hline TM & $25.11 \mathrm{~b} \pm 0.33$ & $25.50 \mathrm{~b} \pm 1.26$ & $23.73 \mathrm{~b} \pm 0.93$ & $24.48 \mathrm{~b} \pm 1.69$ & \\
NP & $35.63 \mathrm{a} \pm 2.28$ & $35.75 \mathrm{a} \pm 2.89$ & $35.02 \mathrm{a} \pm 1.88$ & $32.25 \mathrm{a} \pm 1.01$ & \\
\hline
\end{tabular}

Mean values \pm standard deviations. $\mathrm{N}=3$. Total pigment in AU (AWRI WineCloud ${ }^{\mathrm{TM}}$ ). Values with the same letter in the same column on the same day mean there are no statistically significant differences according to the Tukey test $(\mathrm{p}<0.05)$. TM: traditional maceration. NP: not plunged.

TABLE 5

Free anthocyanins during maceration.

\begin{tabular}{llllll}
\hline & Day 1 & Day 2 & Day 3 & Day 4 & Day 5 \\
\hline TM & $20.71 \mathrm{a} \pm 0.82$ & $30.07 \mathrm{a} \pm 2.05$ & $28.79 \mathrm{~b} \pm 1.36$ & $30.31 \mathrm{~b} \pm 2.80$ & $30.22 \mathrm{~b} \pm 4.45$ \\
NP & $20.59 \mathrm{a} \pm 0.71$ & $26.93 \mathrm{a} \pm 3.27$ & $35.93 \mathrm{a} \pm 2.50$ & $36.68 \mathrm{a} \pm 1.48$ & $41.78 \mathrm{a} \pm 1.93$ \\
\hline & Day 6 & Day 7 & Day 8 & Day 9 & Day 10 \\
\hline TM & $33.35 \mathrm{~b} \pm 1.38$ & $29.04 \mathrm{~b} \pm 1.05$ & $26.72 \mathrm{~b} \pm 2.12$ & $27.00 \mathrm{~b} \pm 1.97$ & $23.64 \mathrm{~b} \pm 0.86$ \\
NP & $41.40 \mathrm{a} \pm 0.38$ & $37.27 \mathrm{a} \pm 2.45$ & $34.48 \mathrm{a} \pm 1.00$ & $34.33 \mathrm{a} \pm 1.63$ & $35.23 \mathrm{a} \pm 0.95$ \\
\hline & Day 11 & Day 12 & Day 13 & Day 14 & \\
\hline TM & $22.52 \mathrm{~b} \pm 0.30$ & $22.81 \mathrm{~b} \pm 1.10$ & $21.14 \mathrm{~b} \pm 0.95$ & $21.43 \mathrm{~b} \pm 1.39$ & \\
NP & $33.19 \mathrm{a} \pm 2.14$ & $33.16 \mathrm{a} \pm 2.63$ & $32.41 \mathrm{a} \pm 1.89$ & $29.54 \mathrm{a} \pm 0.97$ & \\
\hline
\end{tabular}

Mean values \pm standard deviations. $\mathrm{N}=3$. Free anthocyanins in AU (AWRI WineCloud ${ }^{\mathrm{TM}}$ ). Values with the same letter in the same column on the same day mean there are no statistically significant differences according to the Tukey test ( $p<0.05)$. TM: traditional maceration. NP: not plunged.

levels of polymerised pigment (pigmented tannin) did not differ significantly between the NP and TM trials.

Some differences occurred at day 5 , when the NP trial showed a significantly higher pigmented tannin level than the TM trial. This difference was not maintained and, by day 14, TM showed higher pigmented tannin levels than NP, although the difference was not significant. Early oxygen exposure results in polyphenol oxidase enzymatic oxidation in the fermenting must, but more importantly, mechanical cap management such as pumping over and plunging (as with the TM treatment) can give rise to higher oxygen exposure of the bulk of the must compared with the no plunging technique, giving rise to the production of greater amounts of $\mathrm{H}_{2} \mathrm{O}_{2}$ (Waterhouse \& Laurie, 2006). This strong oxidant is capable of reacting with all oxidisable substrates in solution. One such reaction leads to ethanol being oxidised to ethanal (acetaldehyde). Thus the treatment with plunging, $\mathrm{TM}$, would logically have a higher production of $\mathrm{H}_{2} \mathrm{O}_{2}$ than the NP treatment, and a result of this is demonstrated in the higher rate of polymerisation expressed as pigmented tannins found during the maceration period (although only significant on day 9). This agrees with the findings of Bosso et al. (2011), who found a submerged cap (SC) maceration initially showed lower acetaldehyde concentrations than the floating cap (FC) that experienced pump overs. However, as maceration time proceeded they found that the trend for acetaldehyde production was similar in the two trials. The early pump overs in the Bosso et al. (2011) trial were conducted in the absence of air, whereas in our study all the plunging was conducted with aeration. This may have caused a higher oxygen uptake in the TM trial compared with the NP trial, which did not occur in the FC trial. This led to the higher level of pigmented tannins during maceration for the TM compared with the NP, which is similar to the findings when comparing FC with SC (Bosso et al., 2011).

The results found in this study, in which the TM trial has lower total phenolics, tannin and anthocyanin concentrations compared with the NP trial throughout much of the maceration period, are similar to those of the Bosso et al. (2011) study, which found that FC maceration resulted in lower extracted anthocyanins than SC maceration. However, the FC trial involved pump overs, whereas our NP trial involved no mechanical cap disturbance. The result is that the NP trial would have extracted less $\mathrm{K}^{+}$from the skins compared with the TM treatment, leading to a decreased loss of anthocyanins due to anthocyanins being incorporated and lost in potassium bitartrate precipitation. Bosso et al. (2011) also found the FC with pump over had lower tannin extraction and total flavonoids overall at the end of maceration than the $\mathrm{SC}$ with fewer pump overs, again a similar finding to that of the current study.

Figs 1 to 5 show the continued development of the five analysis parameters over the next 11 months and also include data for a middle treatment of partially delayed extraction called Half, where plunging was not started until day 6 of the 14-day maceration period. Tannin, total phenolics, total 
TABLE 6

Pigmented tannins during maceration.

\begin{tabular}{llllll}
\hline & Day 1 & Day 2 & Day 3 & Day 4 & Day 5 \\
\hline TM & $0.60 \mathrm{~b} \pm 0.02$ & $0.80 \mathrm{a} \pm 0.07$ & $1.08 \mathrm{a} \pm 0.07$ & $1.09 \mathrm{a} \pm 0.03$ & $1.14 \mathrm{~b} \pm 0.10$ \\
NP & $0.73 \mathrm{a} \pm 0.01$ & $0.79 \mathrm{a} \pm 0.01$ & $1.18 \mathrm{a} \pm 0.17$ & $1.23 \mathrm{a} \pm 0.07$ & $1.48 \mathrm{a} \pm 0.02$ \\
\hline & Day 6 & Day 7 & Day 8 & Day 9 & Day 10 \\
\hline TM & $1.45 \mathrm{a} \pm 0.05$ & $1.39 \mathrm{a} \pm 0.05$ & $1.38 \mathrm{a} \pm 0.06$ & $1.58 \mathrm{~b} \pm 0.04$ & $1.44 \mathrm{a} \pm 0.08$ \\
NP & $1.41 \mathrm{a} \pm 0.05$ & $1.34 \mathrm{a} \pm 0.16$ & $1.26 \mathrm{a} \pm 0.05$ & $1.32 \mathrm{a} \pm 0.14$ & $1.42 \mathrm{a} \pm 0.06$ \\
\hline & Day 11 & Day 12 & Day 13 & Day 14 & \\
\hline TM & $1.55 \mathrm{a} \pm 0.02$ & $1.61 \mathrm{a} \pm 0.10$ & $1.55 \mathrm{a} \pm 0.05$ & $1.83 \mathrm{a} \pm 0.18$ & \\
NP & $1.46 \mathrm{a} \pm 0.09$ & $1.56 \mathrm{a} \pm 0.16$ & $1.56 \mathrm{a} \pm 0.01$ & $1.63 \mathrm{a} \pm 0.07$ & \\
\hline
\end{tabular}

Mean values \pm standard deviations. $\mathrm{N}=3$. Pigmented tannins in AU (AWRI WineCloud ${ }^{\mathrm{TM}}$ ). Values with the same letter in the same column on the same day mean there are no statistically significant differences according to the Tukey test $(\mathrm{p}<0.05)$. TM: traditional maceration. NP: not plunged.

pigment and pigmented tannin were significantly higher in the NP treatment compared with the other two treatments over much of the post-maceration wine ageing period, such that at day 341 , all of the measured analytes were at significantly higher concentrations in the NP wine. In all cases except for pigmented tannins, the intermediate of half plunging contained the middle concentration of measured phenolic compounds and was significantly higher than the TM treatment.

Total phenolic concentrations for all three treatments levelled off after maceration, as would be expected, with no further extraction possible (Fig. 1). Within this pool of total phenolics, tannin levels continued to rise until points between 90 and 137 days and then became steady for all three treatments (Fig. 2). The increases in tannin over this time are due to ongoing phenolic polymerisation processes in each of the three treatments. Overall, the total phenolic level for each treatment does not change significantly from day 50 to 200 (Fig. 1), but the proportion of phenolics existing as di- and tri-anthocyanidins and short polymeric pigments (SPP) (Harbertson et al., 2003) has increased, giving rise to the higher tannin concentrations shown in Fig. 2. Note that the WineCloud ${ }^{\mathrm{TM}}$ tannin analysis result is based on the MCP (Mercurio \& Smith, 2008) assay and removes more tannin material from the wine than the A-H assay, which does not precipitate the di- and tri-proanthocyanidins and SPP with the bovine protein BSA. This would indicate that polymerisation rates slowed or that competing tannin-removal reactions became significant compared to competing polymerisation reactions. The depolymerisation of ethanal-bridged tannins and the dehydration of an ethanol-flavan-3-ol adduct formed during ethanal-flavan-3-ol condensation, leading to p-vinylphenols and then to more complex compounds in which the ethanal bridges are rearranged, will contribute to lower concentrations of quantifiable tannins (Drinkine et al., 2007). Pigmented tannin concentrations continued to rise until day 341 in all three treatments (Fig. 5), with the NP treatment showing the greatest increase. The formation of pigmented tannin in the NP trial increased at the end of maceration and the concentration became greater than that found in the other two trials between days 70 and 90 .

Total pigment concentrations can also be interpreted as a crude measure of wine colour, and Fig. 3 shows a slow but steady decline from days 5 and 6 for all treatments until after day 225, when the decline almost ceased. Colour stability for each of the three treatments is similar, as can be seen by the very slight negative gradient over the period from day 223 to day 341, in Fig. 3. What this indicates is that the colour stability of the NP treatment is of the same order as that for the TM treatment. If the free anthocyanin concentrations are considered, a similar pattern is evident, where Fig. 4 shows that free anthocyanins in each of the three treatments peak at days 5 and 6; with the Half and TM peaking at lower levels than the NP, but all the treatments steadily declining in free anthocyanins from then on. These results are similar to the overall trends reported in a trial by Perez-Magarino and Gonzalez-San Jose (2004). The rate of decline is similar for all three treatments, again indicating similar colour stability conditions in the treatments between from day 223 to day 341. This is also supported by the results of Bosso et al. (2009), in which a delayed extraction regime consisting of one short pump over per day until $6 \%$ alcohol was reached during fermentation, and then pump overs twice a day, led to significantly higher total anthocyanins and free anthocyanins than was determined in their conventional maceration trial. They reported similar results for total phenolics and proanthocyanidins, where the delayed extraction trial had significantly higher concentrations at racking compared to the conventional maceration reported in our study. Our results at seven months are similar to those of Bosso et al. (2009), who found that total anthocyanins, proanthocyanins, total phenolics and free anthocyanins remained significantly higher in concentration in the delayed extraction trial compared with conventional maceration. They explain the greater extraction as being due to the higher temperature and $\mathrm{pH}$ in the cap, giving rise to higher natural pectolytic enzyme activity in the cap, resulting in the higher polyphenolic content in the delayed extraction trial at racking. However, the Bosso et al. (2009) study reports that, at seven months, the delayed extraction trials had lower values of non- $\mathrm{SO}_{2}$ bleachable pigments (pigmented tannin) compared with the conventional maceration treatment, and this is in contrast to our findings, shown in Fig. 5.

Higher pigmented polymer concentrations leading to increased colour stability have been claimed by Bosso et al. (2009) as the consequence of increased oxygen contact 


\section{Figure 1. Total Phenolics} $n=3$. Error bars \pm 1 Std Dev

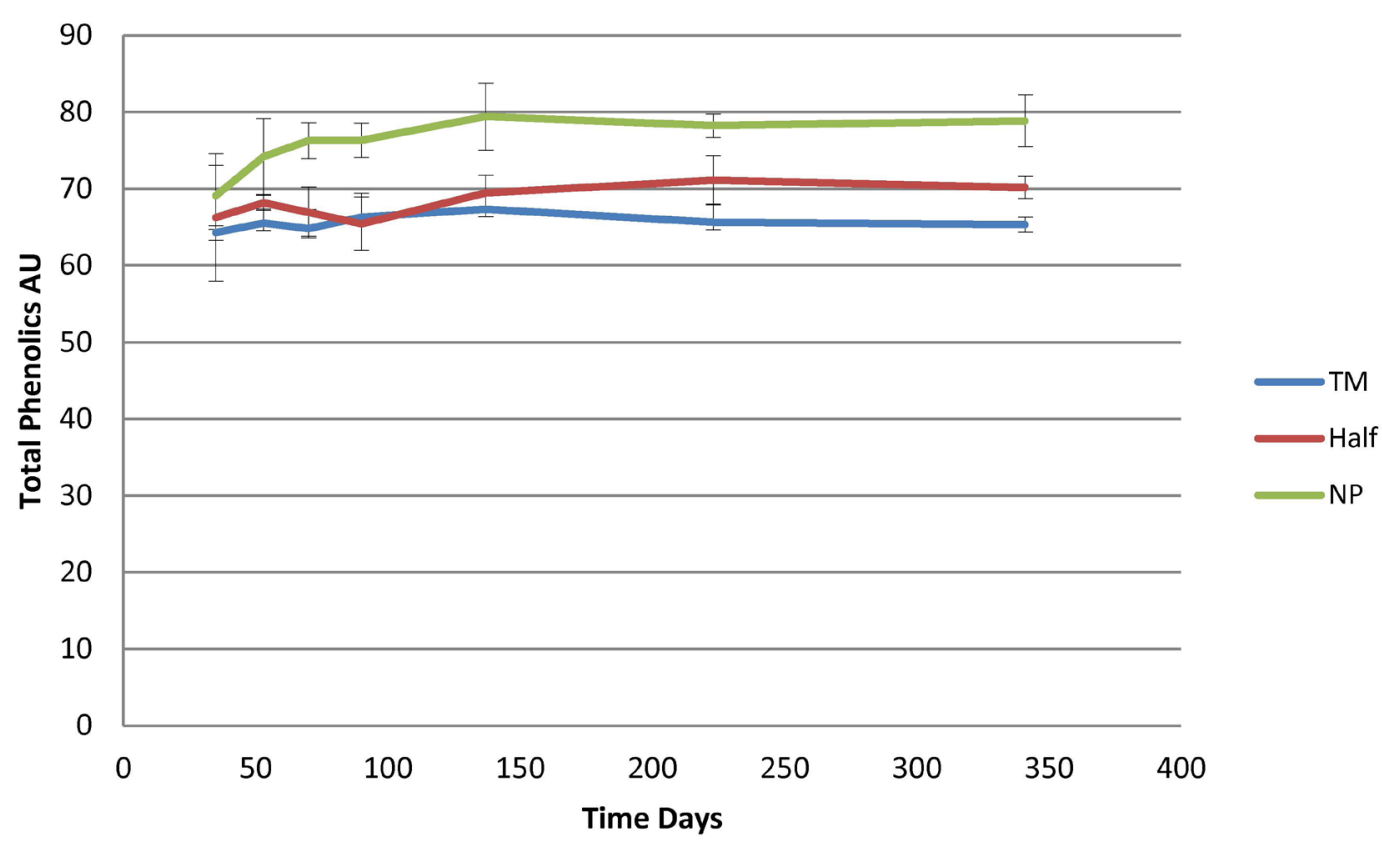

FIGURE 1

Total phenolic contents of the three winemaking procedures post-maceration, beginning at day 35 , expressed in absorbance units. TM: traditional maceration. Half: half plunged. NP: not plunged.

Figure 2. Tannin

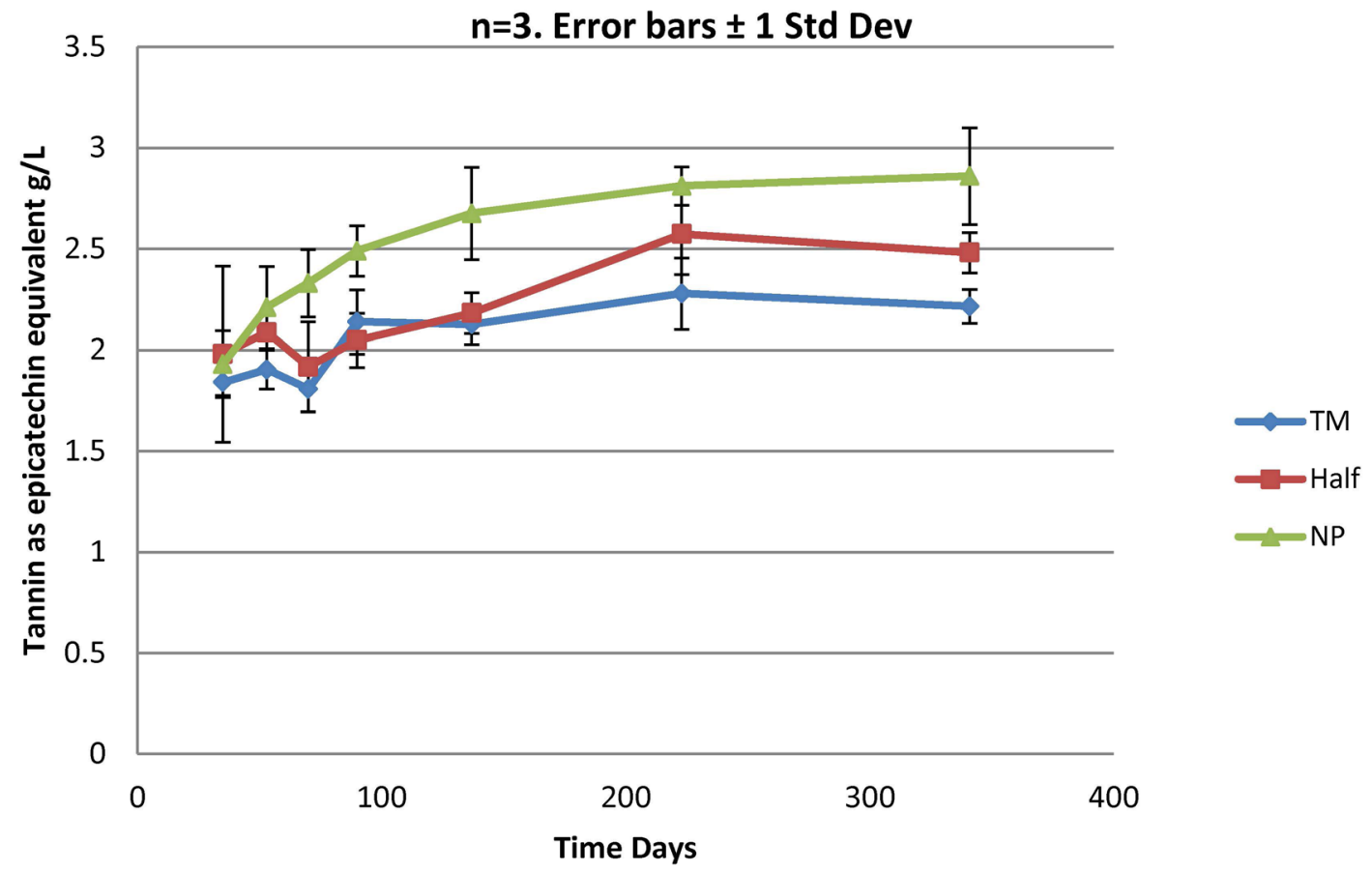

FIGURE 2

Tannin contents of the three winemaking procedures post-maceration, beginning at day 35, expressed as $\mathrm{g} / \mathrm{L}$ epicatechin equivalents. TM: traditional maceration. Half: half plunged. NP: not plunged. 
during fermentation. The improved extraction and retention of free anthocyanin monomers during fermentation and maceration in our $12 \mathrm{~kg} \mathrm{NP}$ trial compared to the TM trial led to higher concentrations of free anthocyanins during wine ageing. This led to increased anthocyanin-tannin polymerisation reactions in the NP trial and therefore higher pigmented tannin concentrations, improving colour stability. Kilmister et al. (2014) explain the notion of an optimum ratio of anthocyanin to tannin in wine for polymeric pigment formation, or long-term colour stability. They also reported that higher anthocyanin concentrations in wines at pressing resulted in wines with higher pigmented polymer concentrations after ageing. Work by Oberholster et al. (2009) and Singleton and Trousdale (1992) also supports this interpretation. However, in a 2010 study, Gonzales-Neves et al. found that, in $70 \mathrm{~kg}$ treatments, TM wines showed the highest anthocyanin content at devatting and that differences were attenuated over time, so that total pigment content of the wines after one year of ageing showed no statistical difference to wines obtained by delayed extraction. They concluded that the pigment profile of the wines depended mainly on age rather than on differences determined by the alternative winemaking techniques evaluated. However, it should be noted that their delayed extraction involved pump overs, which may have influenced the result.

The higher pigmented tannin concentrations in the NP trial compared to TM can also be explained by copigmentation. The earlier observed higher concentration of free anthocyanins and total phenolics in the NP treatment led to higher co-pigmentation rates during maceration, and subsequently to higher levels of pigmented tannins. This is consistent with Boulton (2001), who cites views that co-pigmentation formation can increase the rates of polymerisation, leading to pigmented tannins. Further support for this view can be found in studies by Mirabel et al. (1999) and Eiro and Heinonan (2002).

A further suggestion is that the NP treatment led to lower cell wall material suspension due to less mechanical breakdown of flesh and skin compared with the TM trial with plunging twice a day. This resulted in higher net extractions in the NP trial due to more adsorption of extracted proanthocyanidins onto cell wall material, followed by settling, in the TM treatment. This is supported by the report of Bindon et al. (2010), who cite work by CerpaCalderon \& Kennedy (2008) that showed that the degree of berry crushing significantly altered skin proanthocyanidin extraction, with suspended cell wall material adsorbing the extracted proanthocyanidins.

Identical commercial, non-replicated $4 \mathrm{t}$ trials were carried out during the same 2013 vintage on the same batch of Merlot grapes at Esk Valley Estate. Samples were collected and analysed by the same methods used for the microvinifications. The results showed that, after 90 days, comparable levels of tannin, pigmented tannin and total pigment were found in the resulting commercial trial wines. During maceration the extraction of these analytes showed similar trends between the NP and TM treatments and did not contradict the microvinification results over this time (see Tables 7, 8 and 9).

In an unpublished non-replicated commercial $2 \mathrm{t}$ trial carried out by Musther (2010), using Merlot fruit processed at Mission Estate, Hawke's Bay. The no plunging regime resulted in wines with greater $520 \mathrm{~nm}$ absorbance, $280 \mathrm{~nm}$ absorbance and $520 \mathrm{~nm}$ absorbance after $\mathrm{SO}_{2}$ bleaching, compared with a regime of one plunge per day during maceration.

\section{Figure 3. Total Pigment- Colour $\mathrm{n}=3$. Error bars \pm 1 Std Dev}

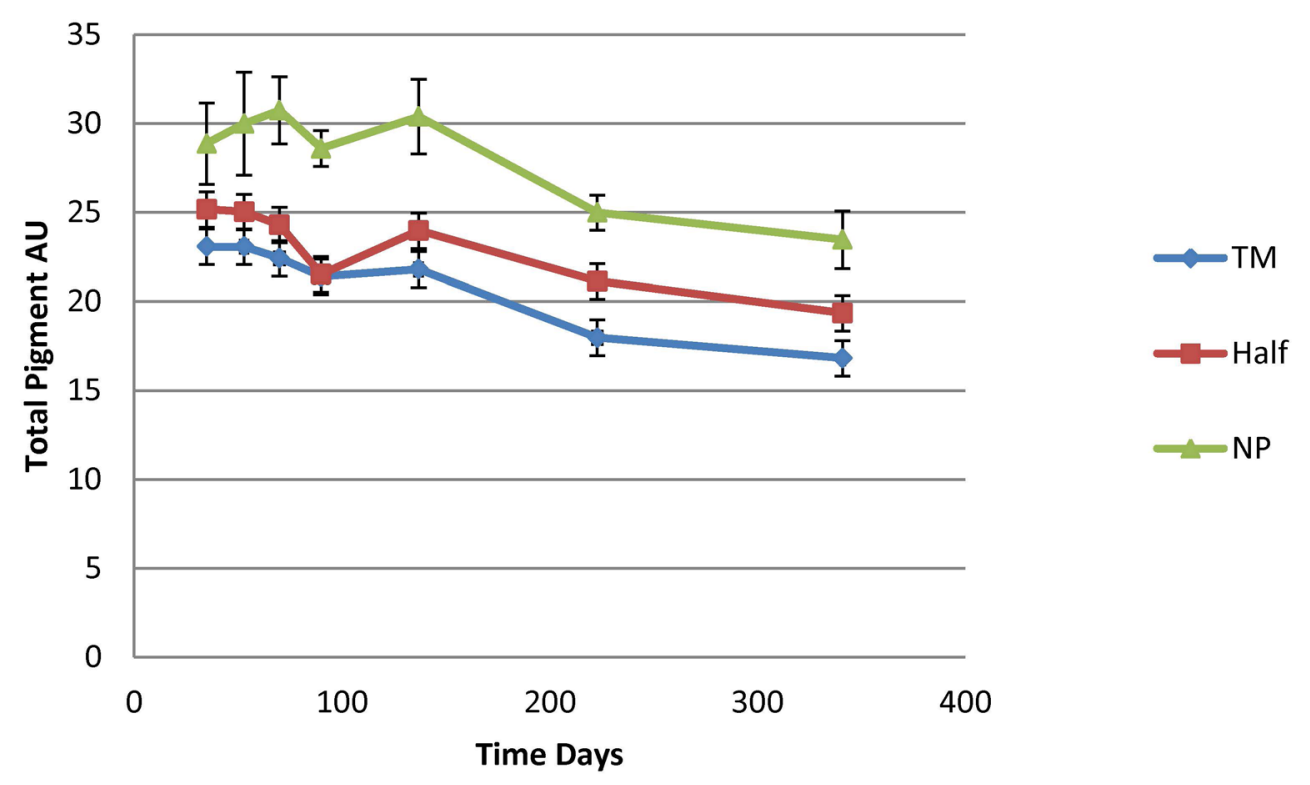

FIGURE 3

Total pigment content of the three winemaking procedures post-maceration, beginning at day 35 , expressed in absorbance units. TM: traditional maceration. Half: half plunged. NP: not plunged. 
TABLE 7

Commercial trial tannin - first 90 days.

\begin{tabular}{|c|c|c|c|c|c|}
\hline & Day 5 & Day 6 & Day 7 & Day 8 & Day 9 \\
\hline $\mathrm{TM}$ & 1.06 & 1.72 & 1.67 & 1.97 & 1.77 \\
\hline \multirow[t]{2}{*}{$\mathrm{NP}$} & 1.01 & 0.74 & 1.3 & 1.55 & 1.31 \\
\hline & Day 10 & Day 11 & Day 12 & Day 13 & Day 14 \\
\hline $\mathrm{TM}$ & 1.86 & 2.15 & 1.98 & 1.63 & 2.09 \\
\hline \multirow[t]{2}{*}{ NP } & 1.53 & 1.35 & 1.80 & 1.67 & 1.91 \\
\hline & Day 53 & Day 90 & & & \\
\hline $\mathrm{TM}$ & 1.82 & 2.19 & & & \\
\hline $\mathrm{NP}$ & 1.76 & 2.19 & & & \\
\hline
\end{tabular}

$\mathrm{N}=1$. Tannins in $\mathrm{g} / \mathrm{L}$ epicatechin equivalent (AWRI WineCloud ${ }^{\mathrm{TM}}$ )

TABLE 8

Commercial trial pigmented tannins - first 90 days.

\begin{tabular}{llllll}
\hline & Day 5 & Day 6 & Day 7 & Day 8 & Day 9 \\
\hline TM & 0.66 & 1 & 0.82 & 0.74 & 0.97 \\
NP & 0.56 & 0.44 & 0.61 & 0.8 & 0.9 \\
\hline & Day 10 & Day 11 & Day 12 & Day 13 & Day 14 \\
\hline TM & 0.98 & 1.04 & 1.05 & 0.85 & 1.22 \\
NP & 0.93 & 0.9 & 0.84 & 0.78 & 0.94 \\
\hline & Day 53 & Day 90 & & & \\
\hline TM & 1.83 & 2.27 & & & \\
NP & 1.78 & 2.11 & & & \\
\hline
\end{tabular}

$\mathrm{N}=1$. Pigmented tannins in AU (AWRI WineCloud ${ }^{\mathrm{TM}}$ ).

TABLE 9

Commercial trial total pigment - first 90 days.

\begin{tabular}{llllll}
\hline & Day 5 & Day 6 & Day 7 & Day 8 & Day 9 \\
\hline TM & 31.11 & 39.58 & 34.78 & 35.29 & 34.99 \\
NP & 31.21 & 24.73 & 34.17 & 36.31 & 33.71 \\
\hline & Day 10 & Day 11 & Day 12 & Day 13 & Day 14 \\
\hline TM & 34.02 & 35.39 & 33.86 & 28.66 & 32.54 \\
NP & 35.24 & 32.84 & 34.53 & 32.38 & 33.71 \\
\hline & Day 53 & Day 90 & & & \\
\hline TM & 29.02 & 28.86 & & & \\
NP & 30.19 & 30.24 & & &
\end{tabular}

$\mathrm{N}=1$. Total pigment in $\mathrm{AU}$ (AWRI WineCloud ${ }^{\mathrm{TM}}$ )

\section{CONCLUSIONS}

The extraction of phenolics (anthocyanins, total phenolics and tannins) and pigmented tannin evolution were significantly different in the winemaking processes studied here and varied as a function of time. At the end of maceration, total phenolics, total pigment and free anthocyanins were significantly lower in concentration in the TM treatment compared with the NP treatment. The tannin concentration also was lower, significantly so over days 10 to 12 . Pigmented tannin was consistently at higher concentrations in the TM treatment, although not significantly so during maceration. The implication here is that the mechanical disruption of the fermenting wine cap extracted less phenolic material than no mechanical disruption of the cap at all. Development over the next 11 months showed a continuation of these differences, although pigmented tannin levels in the NP trial increased at a greater rate than in the TM wine, to the extent that significantly higher stable colour was found in the NP wine from about day 90 onwards.

Lower extraction in the TM wines was partially due to increased exposure to oxygen during mechanical cap management, but also due to the increased disruption of berry solids, leading to more adsorption, oxidation and potassium bitartrate precipitation removing portions of the extracted phenolics. Higher anthocyanin and total phenolic concentrations in the NP wine may have led to higher copigmentation rates, which in turn led to greater pigmented 
Figure 4. Free Anthocyanins

$n=3$. Error bars \pm 1 Std Dev

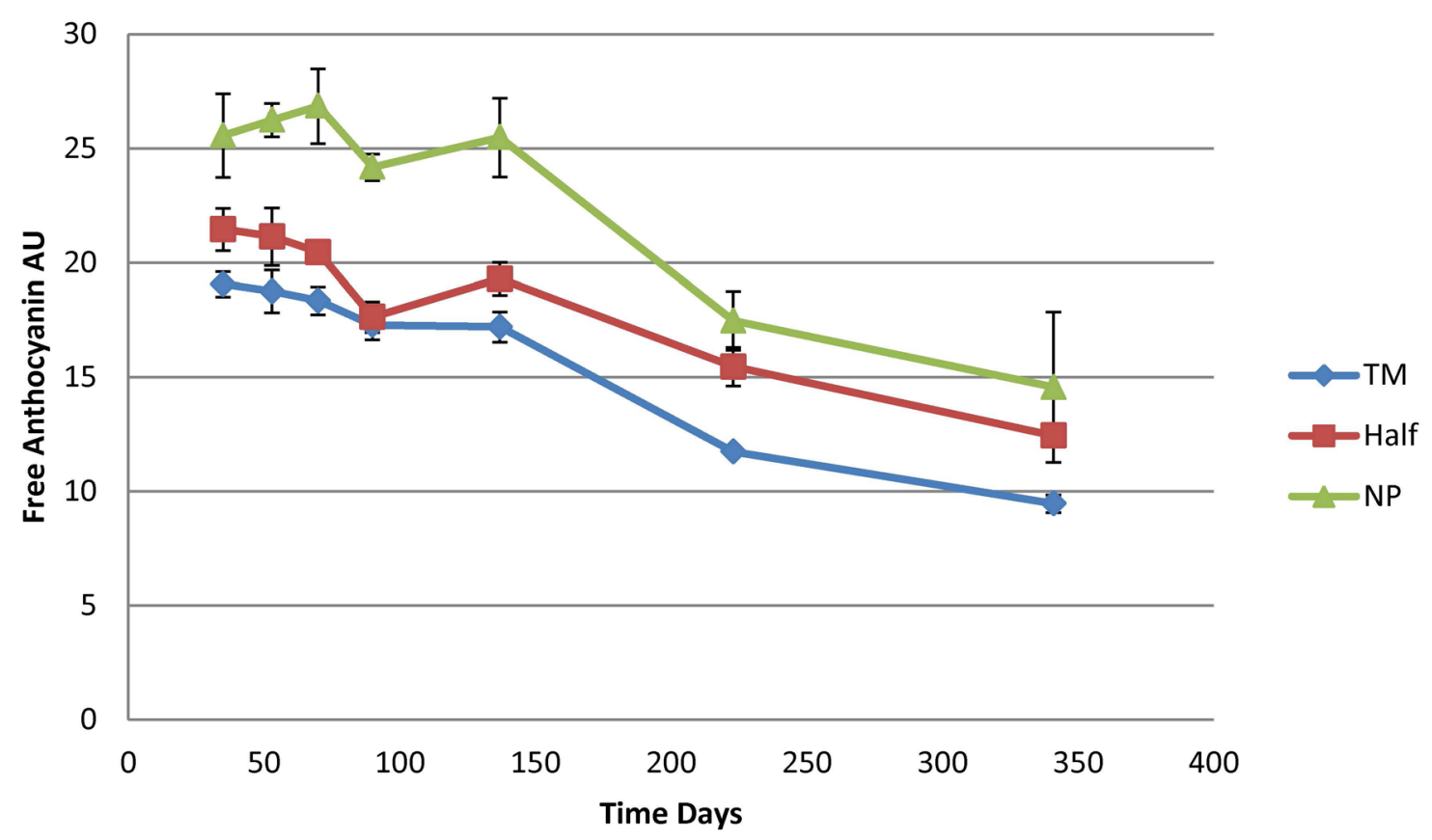

FIGURE 4

Free anthocyanin content of the three winemaking procedures post-maceration, beginning at day 35, expressed as absorbance units. TM: traditional maceration. Half: half plunged. NP: not plunged.

\section{Figure 5. Pigmented Tannin} $n=3$. Error bars \pm 1 Std Dev

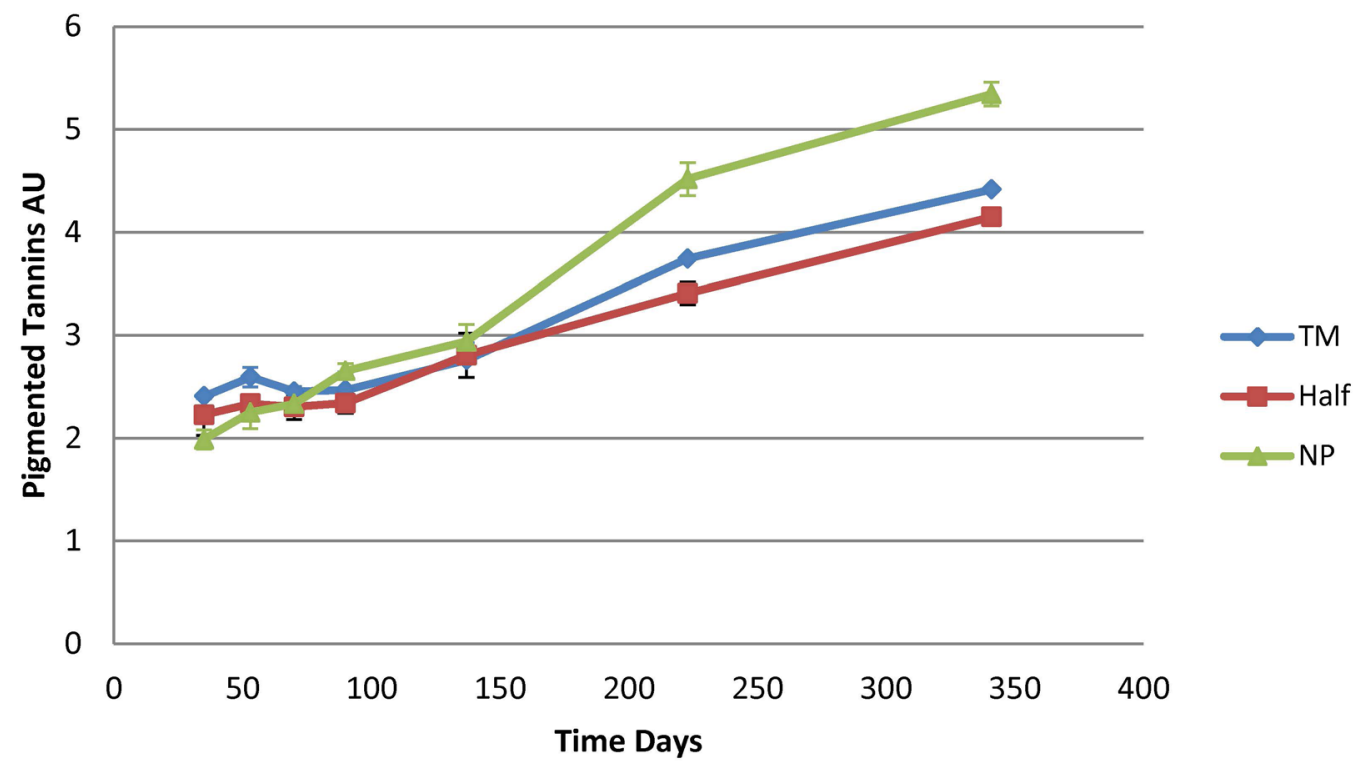

FIGURE 5

Pigmented tannin content of the three winemaking procedures post-maceration, beginning at day 35, expressed as absorbance units. TM: traditional maceration. Half: half plunged. NP: not plunged.

tannin development in the NP wine.

This study shows that the small-scale NP treatment produced Merlot wines with more colour and more stable colour after one year compared with the TM wine.
Winemaking resources are in high demand during vintage time. More efficient use of labour and resources would be enabled by reducing and even eliminating the need for red wine cap management during maceration. The wines 
produced would also exhibit greater colour stability after one year. Further study on a commercial scale and with longer ageing time will help confirm these conclusions.

\section{LITERATURE CITED}

AWRI, 2012. Sample preparation guide - analysing wine and ferment samples for tannin, colour and phenolic measures using the Wine Portal. Retrieved from http:/www.awri.com.au/wp-content/uploads/2013/08/ sample-prep-guide-wine-portal.pdf Website.

Bindon, K.A., Smith, P.A., Holt, H. \& Kennedy, J., 2010. Interactions between grape-derived proanthocyanidins and cell wall material. 2. Implications for vinification. J. Agric. Food Chem. 58(19), 10736-10746.

Bosso, A., Guaita, M., Panero, L., Borsa, D. \& Follis, R., 2009. Influence of two winemaking techniques on polyphenolic composition and colour of wines. Am. J. Enol. Vitic. 60(3), 379-385.

Bosso, A., Panero, L., Petrozziello, M., Follis, R., Motta, S. \& Guaita, M., 2011. Influence of submerged-cap vinification on polyphenolic composition and volatile compounds of Barbera wines. Am. J. Enol. Vitic. 62(4), 503511.

Boulton, R., 2001. The co-pigmentation of anthocyanins and its role in the color of red wine: A critical review. Am. J. Enol. Vitic. 52, 67-87.

Canals, R., Llaudy, M.C., Valls, J., Canals, J.M. \& Zamora, F., 2005. Influence of ethanol concentration on the extraction of color and phenolic compounds from the skin and seeds of Tempranillo grapes at different stages of ripening. J. Agric. Food Chem. 53, 4019-4025.

Casassa, L.F., Beaver, C.W., Mireles, M.S. \& Harbertson, J.F., 2013. Effect of extended maceration and ethanol concentration on extraction and evolution of phenolics, colour components and sensory attributes of Merlot wine. Aust. J. Grape Wine Res. 19, 25-39.

Cerpa-Calderon, F.K. \& Kennedy, J.A., 2008. Berry integrity and extraction of skin and seed proanthocyanidins during red wine fermentation. J. Agric. Food Chem. 56(19), 9006-9014.

Cheynier, V., Duenas-Paton, M., Salas, E., Maury, C., Souquet, J.M., SarniManchardo, P. \& Fulcrand, H., 2006. Structure and properties of wine pigments and tannins. Am. J. Enol. Vitic. 57(3), 298-305.

Chittenden, R., 2008. Co-fermentation of Vitis vinifera L. Syrah with Viognier and its impact on co-pigmentation and polymeric pigmentation. Thesis, University of Auckland, Auckland, New Zealand.

Chittenden, R. \& Smith, P., 2011. Comparison of three different analysis methods for tannin in New Zealand red wines. Am. J. Enol. Vitic. 62, 401A-401A.

Dambergs, R.G., Mercurio, M.D., Kassara, S., Cozzolino, D. \& Smith, P.A., 2012. Rapid measure of precipitable tannins using ultraviolet spectroscopy and chemometrics - application to red wine and inter-laboratory calibration transfer. Appl. Spectroscopy 66(6), 656-664.

De Beer, D., Joubert., E., Marais, J. \& Manley, M., 2006. Maceration before and during maceration: Effects on Pinotage wine phenolic composition, total antioxidant capacity and objective colour parameters. S. Afr. J. Enol. Vitic. 27(2), 137-150.

Drinkine, J., Lopes, P., Kennedy, J.A., Teissedre, P.L. \& Saucier, C., 2007. Ethylidene-bridged flavan-3-ols in red wine and correlation with wine age. J. Agric. Food Chem. 55, 6292-6299.

Eiro, M.J. \& Heinonen, M., 2002. Anthocyanin color behaviour and stability during storage: Effect of intermolecular copigmentation. J. Agric. Food Chem. 50, 7461-7466.
Es-Safi, N., Fulcrand, H., Cheynier, V. \& Moutounet, M., 1999. Studies on the acetaldehyde induced condensation of (-)- epicatechin and malvidin 3-O-gluciside in a model wine solution system. J. Agric. Food Chem 47, 2096-2102.

Fulcrand, H., Duenas, M., Salas, E. \& Cheynier, V., 2006. Phenolic reactions during winemaking and aging. Am. J. Enol. Vitic. 57(3), 289-297.

Gao, L., Girard, B. \& Reynolds, A.G., 1997. Changes in anthocyanins and color characteristics of Pinot Noir wines during different vinification processes. J. Agric. Food Chem. 45, 2003-2008.

Gawel, R., 1998. Red wine astringency: A review. Aust. J. Grape Wine Res. 4, 74-95.

Gil, M., Kontoudakis, N., Gonzalez, E., Esteruelas, M., Fort, F., Miguel Canals, J. \& Zamora, F., 2012. Influence of grape maturity and maceration length on color, polyphenolic composition, and polysaccharide content of Cabernet Sauvignon and Tempranillo wines. J. Agric. Food Chem. 60, 7988-8001.

Gonzales-Neves, G., Gil, G., Barreiro, L. \& Favre, G., 2010. Pigment profile of red wines cv. Tannat made with alternative winemaking techniques. J. Food Comp. Anal. 23, 447-454.

Hagerman, A.E. \& Butler, L.G., 1978. Protein precipitation method for the quantitative determination of tannins. J. Agric. Food Chem. 26, 809-812.

Harbertson, J.F. \& Downey, M.O., 2009. Investigating differences in tannin levels determined by methylcellulose and protein precipitation. Am. J. Enol. Vitic. 60(2), 246-249.

Harbertson, J.F., Picciotto, E.A. \& Adams, D.O., 2003. Measurement of polymeric pigments in grape berry extracts and wines using a protein precipitation assay combined with bisulfite bleaching. Am. J. Enol. Vitic. 54, 301-306.

Iland, P., Bruer, N., Wilkes, E. \& Edward, G., 2004 (1st ed). Anthocyanins (colour) and total phenolics of grape berries. Chemical analysis of grapes and wine: Techniques and concepts. Winetitles, Broadview, Australia.

Iland, P.G., Ewart, A. \& Sitters, J., 1993. Techniques for chemical analysis and stability tests of grape juice and wine. Patrick Iland Wine Promotions, Campbelltown, South Australia.

Kilmister, R.L., Mazza, M., Baker, N.K., Faulkner, P. \& Downey, M.O., 2014. A role for anthocyanin in determining wine tannin concentration in Shiraz. Food Chem. 152, 475-482.

Kovac, V., Alonso, E., Bourzeix, M. \& Revilla, E., 1992. Effect of several enological practices on the content of catechins and proanthocyanidins of red wines. J. Agric. Food Chem. 40, 1953-1957.

Lattey, K.A., Bramley, B.R. \& Francis, I.L., 2010. Consumer acceptability, sensory properties and expert quality judgements of Australian Cabernet Sauvignon and Shiraz wines. Aust. J. Grape Wine Res. 16, 189-202.

Marais, J., 2003. Effect of different winemaking techniques on the composition and quality of Pinotage wine. II. Juice/skin mixing practices. S. Afr. J. Enol. Vitic. 24(2), 76-79.

Mercurio, M.D. \& Smith, P.A., 2008. Tannin quantification in red grapes and wine: Comparison of polysaccharide- and protein-based tannin precipitation techniques and their ability to model wine astringency. J. Agric. Food Chem. $56,5528-5537$.

Mercurio, M.D., Herderich, M.J. \& Smith, P.A., 2007. High throughput analysis of red wine and grape phenolics - adaptation and validation of methyl cellulose precipitable tannin assay and modified Somers color assay to a rapid 96 well plate format. J. Agric. Food Chem. 55, 4651-4657. 
Mirabel, M., Saucier, C., Guerra, C. \& Glories, Y., 1999. Copigmentation in model wine solutions: Occurrence and relation to wine aging. Am. J. Enol. Vitic. 50, 211-218.

Musther, J., 2010. Effects of varying degrees of cap management on phenolic extraction and stability. Thesis, Eastern Institute of Technology, Hawkes Bay, Napier, New Zealand.

Oberholster, A., Francis, I.L., Iland, P.G. \& Waters, E., 2009. Mouthfeel of white wines made with and without pomace contact and added anthocyanins. Aust. J. Grape. Wine. Res. 15, 59-69.

Perez-Magarino, S. \& Gonzalez-San Jose, M.L., 2004. Evolution of flavanols, anthocyanins, and their derivatives during aging of red wines elaborated from grapes harvested at different stages of ripening. J. Agric. Food Chem. 52, 1181-1189.

Ribereau-Gayon, P., Glories, Y., Maujean, A. \& Dubourdieu, D., 2006. Handbook of enology. The chemistry of wine stabilization and treatments. John Wiley \& Sons Ltd., Chichester.

Sacchi, K.L., Bisson, L.F. \& Adams, D.O., 2005. A review of the effect of winemaking techniques on phenolic extraction in red wines. Am. J. Enol Vitic. 56(3), 197-206.
Sarneckis, C.J., Dambergs, R.G., Jones, P., Mercurio, M., Herderich, M.J. \& Smith, P.A., 2006. Quantification of condensed tannins by precipitation with methyl cellulose: Development and validation of an optimised tool for grape and wine analysis. Aust. J. Grape. Wine. Res. 12, 39-49.

Singleton, V.L. \& Trousdale, E.K., 1992. Anthocyanin-tannin interactions explaining differences in polymeric phenols between white and red wines. Am. J. Enol. Vitic. 43, 63-70.

Somers, T.C. \& Evans, M.E., 1977. Spectral evaluation of young red wines: Anthocyanin equilibria, total phenolics, free and molecular SO2, «chemical age». J. Agric. Food Chem. 28, 279-287.

Vrhovsek, U., Vanzo, A. \& Nemanic, J., 2002. Effect of red wine maceration techniques on oligomeric and polymeric proanthocyanidins in wine, cv. Blaufrankish. Vitis 41, 47-51.

Waterhouse, A.L. \& Laurie, V.F., 2006. Oxidation of wine phenolics: A critical evaluation and hypotheses. Am. J. Enol. Vitic. 57(3), 306-313.

Weber, W., Greve, K., Durner, D., Fischer, U. \& Winterhalter, P., 2013. Sensory and chemical characterisation of phenolic polymers from red wine obtained by gel permeation chromotography. Am. J. Enol. Vitic. 64(1), 15- 